\title{
The Union and Non-Union Wage Differential in the New Zealand Public Service
}

\author{
Goldie Feinberg-Danieli and Zsuzsanna Lonti
}

\section{Introduction}

What do unions do? The major objective of unions is to improve the terms of conditions of employment for their members. At the same time, unions have a considerable impact on the employment conditions of not only their own members but non-unionised workers as well. One of the most important employment terms unions negotiate is wages. As a result, wage bargaining has been identified as a primary function of unions, and differences in wages between union and non-union members are considered an important measure of union power. In most countries this differential is called the 'union/non-union' wage differential. In New Zealand, however, there are employees who are union members but are not covered by collective agreements, contrary to the more common occurrence in other countries (e.g. the United States and Canada), where non-union members are often covered by collective agreements. Therefore, in New Zealand the differential should be more precisely called the 'collective versus individual' wage differential. In this article we focus on the raw 'collective' wage differential, but due to convention we still call it the 'union' wage differential.

There is a large body of empirical research internationally on the union/non-union wage differential, using both micro- and macroeconomic models. Those studies almost uniformly conclude that union members receive higher wages then their non-union counterparts. We explore whether this is the case in the New Zealand Public Service (NZPS) as well.

Due to data limitations the union premium has not previously been calculated in New Zealand. The New Zealand State Services Commission's (SSC) Human Resource Capability (HRC) survey - the only available source of individual-level data in New Zealand on collective agreement coverage and union membership allows us to examine the differences in average wages between NZPS employees who are employed on individual agreements and those employed on collective agreements. The HRC survey of $2005^{1}$ collects a wide range of information on people employed in the NZPS, including all permanent and temporary employees, at the same time excluding those who work on a casual or as-required basis, and chief executives. The data was collected by the SSC from all 35 public service departments, which employed approximately 40,000 full-time and part-time employees in 2005. Of those employees, $54 \%$ were covered by collective agreements and $58 \%$ of them were union members.

We find that in the NZPS, employees on individual contracts earn significantly higher wages then those who are covered by collective agreements, contrary to the experience of other countries. Looking for the factors contributing to this phenomenon, we carry out comparisons of average wages of employees on individual versus collective agreements by gender, employment type, occupation, ethnicity, age, tenure and employer size. The negative union wage differential persists across most employee subgroups. We also provide some preliminary explanations for our unusual findings, although without carrying out further empirical work the reasons for the existence of the negative union wage premium cannot be ascertained.

\section{Brief history of employment relations in the NZPS}

A brief overview of employment relations, and specifically the role of unions, in the NZPS since the mid-late 1980s, when major restructuring of the service started, is essential in order to understand the climate that NZPS employers, unions and employees operate in today.

The 2005 survey reflects the New Zealand Public Service as of 30 June 2005. We would like to thank the State Services Commission for allowing us access to the data. 
Prior to 1988, employment relations in the service were centralised. The SSC acted as the government's central employing agency of staff, negotiating and monitoring their employment conditions. NZPS employee organisations were allowed to register as trade unions for the first time under the Labour Relations Act 1987. These registered unions enjoyed the exclusive right to represent the group or groups of workers defined in the union's membership rules in negotiations for an award or agreement (Walsh et al., 2001). Public sector unions enjoyed a high level of membership.

The process of decentralisation in the service had begun with the State Services Act of 1988. Under this act, chief executives became employers of their staff, and occupational bargaining was replaced with departmental-level agreements as the primary means of pay fixing, an arrangement that continues to this date. Management positions, at all levels, were removed from collective bargaining coverage, which was replaced by fixed-term individual contracts.

Further major changes occurred in the industrial relations environment in New Zealand, including its public service, with the introduction of the Employment Contracts Act (ECA) in 1991. The ECA showed an explicit preference for individual contracts over collective bargaining in establishing conditions of work. Discrimination on the grounds of membership or non-membership of a union was prohibited. Unions were not considered different from any other non-trading body corporate; union membership was voluntary and employees could authorise any bargaining agent to negotiate individual or collective contracts. This resulted in a dramatic decline in union density ${ }^{2}$ across all industries. While in 1991 union density was $42.3 \%$, by 1999 it had declined to $17.5 \%$; however, the decline in union density was smallest in the public and community services. Public servants were encouraged to leave collective contracts in favour of individual contracts, which led to a considerable reduction in union membership and to sizeable wage differentials between the more senior, highly-skilled public servants and those in the lower paid occupations. Furthermore, where a collective contract was in place employers often extended the same conditions to non-union employees, creating fertile ground for 'free-riding' (Harbridge and

2 Union density equals union membership divided by total employed labour force.
Honeybone, 1996). Unions, including public service unions, became weak and deeply compromised (Walsh et al., 2001).

The employment relations climate changed again with the introduction of the Employment Relations Act 2000, which gives unions a monopoly over collective bargaining, promotes the concept of 'good faith' bargaining and supports multi-employer bargaining. However, bargaining is still completely decentralised in the NZPS, where there is exclusively single-employer bargaining. Still, each department has full control over the determination of wages and other conditions for their staff. At the same time, departments are advised by the SSC to avoid setting precedents or implementing proposals that have a likelihood of 'flow on' to other parts of the service.

\section{The size and determinants of the union wage differential in other countries}

Collective bargaining is the most important tool unions use in New Zealand to achieve gains for their members. Wage bargaining is identified as a primary function of unions. However, unions have a considerable impact on the rewards of not only their own members but non-unionised workers as well. Unions often play a significant role in improving minimum standards for all employees and set a pay standard that non-union employers often follow; this is called the 'union spillover effect'.

It is well established internationally that unions generally obtain higher wages for union members, creating a 'union premium' that often non-members receive as well (e.g. Freeman and Medoff, 1984; Belman and Voos, 2004). However, Peetz (2001) finds that Australian employees on individual contracts often experience superior terms and conditions to those of employees on collective agreements, so in fact having a 'non-union premium'. He argues that employers may offer employees a higher wage through individual contracts than is available through collective bargaining for the same type of work in order to induce employees to forsake union coverage. This impact of the unions is called the 'union threat effect' and has been identified in other jurisdictions as well.

Union/non-union wage differentials were estimated for several countries, and a number of factors were also 
identified that explain the size of the gap. Economists differentiate between 'gross (or raw) wage differential' and the 'adjusted (net) wage differential', being the differential when differences in various individual and workplace characteristics are adjusted for. These adjustments usually reduce the raw differential substantially.

The magnitude of the union wage premium varies from country to country. Due to data constraints, the union wage premium has not been calculated in New Zealand. For Australia, the most recent study puts the net union/ non-union wage differential at between $1 \%$ and $6 \%$ (Wooden, 2001), using various assumptions for union activities. In the US the net union wage premium has been estimated in the range of 15-20\% (Blanchflower and Bryson, 2004). In the UK the net union wage premium amounts to around 5\% (Metcalf et al., 2001). In Canada most recent estimates put the gross union wage differential at $14 \%$ and the net, adjusted differential at 7\% (Fang and Verma, 2002).

In the literature, both employee characteristics - such as age, tenure, occupation, race, sex, education, skilllevel and marital status - and industry and firm characteristics - e.g. firm size, geographic location, firmlevel bargaining - were found to have an impact on the size of the union wage premium. Freeman and Medoff (1984) established that in the US the union wage differential was largest for the youngest, low-tenured and lowest paid workers, and smallest for prime-aged, long-tenured and the highest paid employees. The union wage effect was also larger for non-whites than for whites, for blue-collar workers than for white-collar workers, and for males compared to females. However, the union wage differential fell with firm-level contracts (decentralised bargaining, for example, having a negative effect) and the size of the work site.

An almost universal finding is that union/non-union wage differentials are larger for lower-skilled than for higher-skilled workers (e.g. Freeman, 1982; Mishel and Walters, 2003). Only one study (Hirsch and Schumacher, 2001) has concluded that union wage effects are highly similar across workers with different levels of skills.

Hansen (1998), focusing on the US, found that the union/non-union earnings ratio was greater for women than for men and for blacks and Hispanics than for whites. In a recent study, Blanchflower and Bryson
(2004), who updated Freeman and Medoff's earlier, 1984 study, conclude that in the US, variation in the industry-level union wage premium remained; that the state-level union premium varied less than the occupation- and industry-level premium; and that union workers remained better able than non-union workers to resist employer efforts to reduce wages when market conditions were unfavourable.

Findings are somewhat contradictory on the impact of union density on the size of the union wage premium. Card (2001) finds that, in spite of falling union density in the US, union/non-union wage differentials from 1973 to 1993 have been largely unchanged. At the same time, Bellman and Voos (2004) argue that falling union density in the US from 1979 to 1996 has been accompanied by a decline in the union wage premium. Blanchflower and Bryson (2004) suggest that the relationship between union density and union wages depends on the level of density. They argue that a strong effect would be achieved when density is higher than $40 \%$. Wooden (2001) has also shown that in Australia, strong union presence - where the majority of workers are covered by collective agreements - confers a wage advantage in the order of $15-17 \%$, which applies to members and non-members alike. Peetz (2001) has pointed out that in voluntarist regimes collective bargaining is strengthened when union density is higher; but while it is possible in many regimes to have union members who are not covered by collective bargaining, in such circumstances unions are largely ineffective in achieving gains for their members. In more recent research, Waddoups (2005) suggests that where union density is high it is likely that the provisions of negotiated collective agreements will extend to similar, nonunionised employees. In his findings not only do workers receive a premium for union membership, but the union premium is higher in a high-density industry.

We came across only a few studies focusing on the union wage premium in the public sector. There seems to be a consensus in the US and Canadian literature that the union differential is lower in the public sector, and, more specifically, in central government, than in the private sector (Freeman and Medoff, 1984; Bender, 1998). However, Blanchflower and Bryson (2004) found that the public sector wage premium was similar to those in the private sector. Kornfeld's 1993 study of Australian union wage premiums finds that the union premium exists primarily in the private sector, and he concludes 
that public sector unions in Australia tend to raise wages for all employees in the public sector.

In summary, the literature shows that in most instances union workers receive higher pay than comparable nonunion workers, with the size of the premium varying over time and across countries. The following factors have been identified in contributing to the size of union/ non-union wage differential: union density, collective bargaining coverage, size of establishment, industry, region, age, gender, race, occupation, education, term of agreement, ethnicity, marital status, and tenure with current employer and in a given occupation.

\section{Analysis: what is happening in the NZPS?}

Our analysis is based on the SSC's 2005 HRC survey data. In the survey, wages are defined as the annual fulltime base salary as of 30 June 2005. From the explanatory variables that had been identified in the literature we were able to compare the average wages for employees on individual versus collective agreements by gender, age, ethnicity, occupation, term of employment, hours of work, the union the employees belong to, tenure and the size of the employer. ${ }^{3}$

Table 1 contains the basic descriptives for the variables that our research focuses on. It shows that the NZPS employed 40,325 employees in 2005 . Of these, $59 \%$ of the workforce are female, and $54 \%$ are employed on collective agreements, while $58 \%$ are union members. Almost $60 \%$ of the employees are New Zealand European and $16 \%$ are Maori. Ninety per cent of the workforce are permanent employees and work full time. Most NZPS employees work for large organisations with 500 or more employees. The largest occupational group is associate professionals (34.6\%), followed by professionals (29.2\%). Clerks constitute $17.5 \%$ of the workforce, while corporate managers represent almost

3 Ethnicity categories include: New Zealand Maori; New Zealand European; Pacific Island; Asian; other European; and Other. 'Occupation' is based on the New Zealand Standard Classification of Occupation at the two-digit level. However, we created more aggregate occupational categories, as follows: legislative and administrative workers; corporate managers; professionals; associate professionals; clerks; and all other workers. 'Term of employment' includes two categories: (1) fixed - limited (contract/ agreement with a specified end date) and (2) open (permanent employee). 'Hours of work' differentiates between full-time employees with more than 30 hours per week and part-time employees with less than 30 hours per week. 'Tenure' is employment with a department.
$10 \%$. The bulk of the employees are in the 30-50 age group. Surprisingly, almost $21 \%$ of the workforce have less than one year's experience with their department and $28 \%$ have only one to three years' experience. This means that almost half of the NZPS employees have quite limited experience with their department, while fewer than $30 \%$ have more than 10 years' experience. However, as employees often move across departments, people might have more experience within the service.

Slightly more women $(55 \%)$ are employed on collective agreements then men $(53 \%)$, while only $16 \%$ of the employees on fixed-term contracts are on collectives. Seven per cent of union members are on individual contracts; $55 \%$ of full-time employees and $42 \%$ of parttime employees are on collectives. The unionisation rate for Pakeha $(53.6 \%)$ is quite similar to the overall unionisation rate of the public service workforce (54.3\%), while Maori are somewhat more highly organised (61.3\%). The Public Service Association (PSA) is the largest union in the sector, representing $76 \%$ of union members. There are a few other unions that operate in some departments and compete with the PSA, such as the National Union of Public Employees and Taxpro. A small proportion of employees are members of other unions, for example the Central Amalgamated Workers' Union, Finsec (the country's financial sector union) and the New Zealand Educational Institute.

Unionisation seems to be positively related to employer size: the larger the employer, the higher the ratio of employees on collective agreements. There seems to be a strong association between age and being on collectives, as well as between tenure and unionisation. This means that the older a person is, the more likely it is that he or she will be on a collective. The same applies to tenure: the more tenure a person has, the more likely he or she will be unionised. From the various occupations, the 'other workers' group, which contains mainly tradespeople, is the most highly organised $(73.8 \%)$, followed by associate professionals $(66 \%)$ and clerks (63.8\%); $42 \%$ of professionals are on collective agreements. Corporate managers are the group least organised, with one in five corporate managers on collectives. This is still considered a high ratio considering the concerted efforts by various governments to push corporate managers onto individual contracts since the inception of state sector 
reforms in the late 1980s. Differences in unionisation rates between the various occupational groups might also reflect a negative relationship between job responsibilities and being on a collective. In sum, these results point to significant compositional differences between unionised and non-unionised workers - by age, tenure, occupation, full-time/part-time status and employer size - that could explain part of the wage gap.

Table 2 compares mean wages for employees on collective and individual agreements by gender, agreement term, union membership, hours of work, employer size, occupation, age, tenure and ethnicity. In contrast to most of the findings of the international literature, but in line with a relatively recent Australian study (Peetz, 2001), we have found that a substantial negative union premium exists in the NZPS. On average, NZPS employees on collective agreements earn $23 \%$ less than those employed on individual contracts. Only in the case of part-time employees do those on collective agreements earn more than those on individual contracts - the union premium for them is $5 \%$ - and employees in the occupational group 'other workers' - which covers mainly blue-collar workers earn roughly the same irrespective of whether they are employed on collective or individual agreements. Further, looking at the data by occupation, the differential is largest for diplomats $(-50 \%)$, followed by corporate managers, where those on collectives earn $30 \%$ less than managers on individual contracts. There is a substantial negative differential $(-10 \%)$ for professionals, and there is a small $(-3 \%)$ differential for both associate professionals and clerks. In the whitecollar occupations the size of the differential seems to be related to the amount of responsibility required for the job. This is in line with the findings of Peetz (2001), who similarly found that in Australia employees on individual contracts earn more than those on collectives, and linked this to occupational differences. Many previous studies also show larger union gains for blue-collar workers than for white-collar workers (Card, 2001; Mishel and Walters, 2003), and this is substantiated in the NZPS data as well.

Our results seem also to be in line with the literature's finding that the union/non-union wage differentials are larger for lower-skilled than for higher-skilled workers (Freeman, 1982; Mishel and Walters, 2003). The twist in the NZPS results is that lower-skilled people on collectives still earn less than their colleagues on individual contracts, but the negative differential is smaller for the lower-skilled occupational groups than for the higher-skilled ones. At the same time, union density might also be related to the size of the union/ non-union wage differentials by occupation; like 'other workers', associate professionals and clerks are all highly unionised.

In terms of gender, males on collective agreements earn $30 \%$ less than males on individual contracts, while for females the negative union differential in smaller: $-17 \%$. This is in line with the findings of the international literature that unions provide greater gains for females than for males (Hansen, 1998). In the absence of multivariate analysis we could only speculate about the reasons for the significant difference in the differential by gender. One contributing factor might be occupational differences across the genders: females congregating in lower paid occupations while males more typically hold more senior and managerial positions, which command higher salaries. At the same time, senior and managerial employees are more likely to be employed on individual contracts.

Turning to employer size, the smaller the organisation, the larger the negative union premium. In organisations with fewer than 100 workers, employees on collective agreements earn 33\% less than employees on individual agreements, while in organisations with over 500 employees workers on individual agreements earn 21\% more then their counterparts on collectives. This might be related to union representation, as smaller organisations have much lower union density than larger ones.

Looking at the size of the differential by age, it has been established in the literature that the union wage effect is largest for the youngest workers and smallest for prime-aged workers (Freeman and Medoff, 1984). Our findings are consistent with those results. Although in the NZPS a negative union wage differential exists for all age groups, it is smallest for those 25 years of age or younger $(-2.4 \%)$, and steadily increases until the 51-55 age group $(-34 \%)$, then slowly declines to $-25 \%$ for those aged over 61 . The same pattern is followed with tenure, although the differences between the various groups are less pronounced: people with less than one year of tenure on collectives earn $20 \%$ less than people with more than 20 years of service, who earn $36 \%$ less on collectives than on individual contracts. 
By term of agreement, open-term employees on collective agreements earn $26 \%$ less than their counterparts on individual contracts. In comparison, employees on fixed-term agreements who are covered by collective contracts earn 19\% less than employees on collectives.

Finally, by ethnicity, our literature review shows that the union/non-union earnings ratio in the US was greater for blacks and Hispanics than for whites, meaning that unions provide more gains for groups that are traditionally disadvantaged in the labour market (Hansen, 1998). We concur with those findings, although a negative union premium still exists for both Pakeha and Maori in the NZPS. However, the gap is wider for Pakeha $(-25 \%)$ than it is for Maori $(-18 \%)$.

\section{Conclusion}

We set out to compare the wages of NZPS employees on collective versus individual agreements. We calculated the raw average collective/individual wage differential and compared the differentials for major subgroups of employees. Contrary to the general findings in the international literature, employees on collective agreements in the NZPS earn substantially less than employees on individual contracts. The negative wage differential persists across most employee subgroups. However, New Zealand public sector unions seem to deliver better results for part-timers, blue-collar workers, young workers and lower-skilled white-collar workers, groups that are traditionally disadvantaged in the labour market. Alternatively, the relatively little bargaining power these employee group members have individually could be reflected in the differentials.

Our results show that, in spite of the relatively high unionisation rates in the NZPS, unions in this sector are not able to deliver higher wages to their members than employees on individual contracts can negotiate for themselves. Our work is only the first step in documenting the union/non-union wage differential in the New Zealand public service. We plan to carry out multivariate analysis, including decomposing the raw union/non-union wage gap, which will allow us to separate out the impact of compositional differences between union and non-union members on the wage differential from the impact of unions. In the meantime, we could only speculate on the reasons for the unexpected findings.
Most unions in the public sector were established relatively recently (since 1987), and under the award system public sector employees and their associations had enjoyed a sheltered existence. It is most likely that the decentralisation of collective bargaining to the departmental level, combined with prolonged budget constraints imposed on departments by successive governments, contributed as much to the loss of bargaining power of public sector unions as did the decidedly anti-union stance of the Employment Contracts Act. The ECA did weaken unions, and most unions were not ready and did not have the time to develop tools to deal with the drastic changes. While public sector unions were more successful than other New Zealand unions in keeping members, their declining union power might be reflected in the wage outcomes of their negotiations. During the ECA period, many public sector unions were not able to negotiate wages as part of collective bargaining. Even in 2003, around $50 \%$ of the public sector collective agreements did not include wages. At the same time, it has been well established (Walsh et al., 2001) that the drastic changes in the economic and employment relations environment from 1987 created increased income inequalities in New Zealand society, providing higher returns for highly educated professionals and declining real incomes for lower-skilled employees. This general tendency could be reflected in the stronger bargaining position of professionals and managerial employees on individual contracts in the NZPS. 
Table 1: Individual, job and workplace characteristics of the NZPS (2005)

\begin{tabular}{|c|c|c|c|}
\hline & Employees & Collective & Individual \\
\hline No. of employees & 40,325 & 21,879 & 18,446 \\
\hline Women & 23,843 & 13,107 & 10,735 \\
\hline Men & 16,480 & 8,772 & 7,708 \\
\hline Open-term & 36,612 & 21,281 & 15,331 \\
\hline Fixed-term & 3,713 & 598 & 3,115 \\
\hline Union member & 23,281 & 21,653 & 1,628 \\
\hline PSA & 17,664 & 16,367 & 1,297 \\
\hline Full-time & 36,733 & 20,357 & 16,376 \\
\hline Part-time & 3,592 & 1,522 & 2,070 \\
\hline \multicolumn{4}{|l|}{ Employer size (ees): } \\
\hline$\leq 100$ & 339 & 47 & 292 \\
\hline $101-500$ & 3,130 & 1,008 & 2,122 \\
\hline $501+$ & 36,856 & 20,824 & 16,032 \\
\hline \multicolumn{4}{|l|}{ Occupation: } \\
\hline Corporate managers & 3,89 & 763 & 3,132 \\
\hline Professionals & 11,779 & 4,976 & 6,803 \\
\hline Associate profs & 13,960 & 9,206 & 4,754 \\
\hline Clerks & 7,047 & 4,497 & 2,550 \\
\hline Legislative and admin. & 110 & 2 & 83 \\
\hline Other workers & 3,078 & 2,272 & 806 \\
\hline \multicolumn{4}{|l|}{ Age: } \\
\hline$\leq 25$ & 3,285 & 1,551 & 1,734 \\
\hline $26-30$ & 4,323 & 2,051 & 2,272 \\
\hline $31-35$ & 5,061 & 2,540 & 2,521 \\
\hline $36-40$ & 5,573 & 2,969 & 2,604 \\
\hline $41-45$ & 6,230 & 3,483 & 2,747 \\
\hline $46-50$ & 5,568 & 3.231 & 2,337 \\
\hline $51-55$ & 4,412 & 2,626 & 1,786 \\
\hline $56-60$ & 3,218 & 1,995 & 1,223 \\
\hline
\end{tabular}




\begin{tabular}{|r|r|r|r|}
\hline$\geq 61$ & 1,873 & 1,210 & 663 \\
\hline Tenure (years): & & & \\
0 & 8,353 & 2,736 & 5,617 \\
$1-3$ & 11,448 & 5,529 & 5,919 \\
$4-5$ & 4,556 & 2,656 & 1,900 \\
$6-9$ & 4,888 & 2,928 & 1,960 \\
$10-19$ & 7,278 & 5,357 & 1,921 \\
$20+$ & 3,801 & 2,673 & 1,128 \\
Ethnicity: & & & 10,868 \\
\hline Pakeha & 23,446 & 12,578 & 2,421 \\
\hline Maori & 6,252 & 3,831 & \\
\hline
\end{tabular}

Table 2: Comparison of mean wages and the collective/individual wage differential

\begin{tabular}{|c|c|c|c|c|}
\hline & All $(\$)$ & Collective $(\$)$ & Individual (\$) & $\begin{array}{c}\text { Wage } \\
\text { Differential (\%) }\end{array}$ \\
\hline Total & 50,884 & 44,569 & 58,376 & -0.24 \\
\hline Women & 47,103 & 43,193 & 51,878 & -0.17 \\
\hline Men & 56,349 & 46,624 & 67,416 & -0.31 \\
\hline Open -term & 51,430 & 44,749 & 60,705 & -0.26 \\
\hline Fixed- term & 45,001 & 38,154 & 46,911 & -0.19 \\
\hline Union member & 45,699 & 44,537 & 61,155 & -0.27 \\
\hline PSA & 45,206 & 43,962 & 60,904 & -0.28 \\
\hline Full-time & 52,067 & 44,911 & 60,962 & -0.26 \\
\hline Part-time & 38,791 & 39,986 & 37,911 & 0.05 \\
\hline \multicolumn{5}{|l|}{ Employer size (ees): } \\
\hline$\leq 100$ & 88,213 & 61,237 & 92,555 & -0.34 \\
\hline $101-500$ & 66,250 & 54,111 & 72,016 & -0.25 \\
\hline $501+$ & 49,236 & 44,069 & 55,948 & -0.21 \\
\hline \multicolumn{5}{|l|}{ Occupation: } \\
\hline Corporate managers & 84,676 & 58,354 & 91,089 & -0.36 \\
\hline Professionals & 58,988 & 55,156 & 61,790 & -0.11 \\
\hline
\end{tabular}




\begin{tabular}{|c|c|c|c|c|}
\hline Associate profs & 41,889 & 41,333 & 42,965 & -0.04 \\
\hline Clerks & 38,744 & 38,1 & 39,756 & -0.04 \\
\hline Legislative $\&$ admin. & 170,506 & 95,839 & 194,796 & -0.51 \\
\hline Other workers & 41,599 & 41,730 & 41,232 & 0.01 \\
\hline \multicolumn{5}{|l|}{ Age: } \\
\hline$\leq 25$ & 35,369 & 34,928 & 35,763 & -0.024 \\
\hline $26-30$ & 43,011 & 39,766 & 45,940 & -0.13 \\
\hline $31-35$ & 48,770 & 43,512 & 54,067 & -0.20 \\
\hline $36-40$ & 51,867 & 44,643 & 60,104 & -0.26 \\
\hline $41-45$ & 53,691 & 45,933 & 63,526 & -0.28 \\
\hline $46-50$ & 55,687 & 46,922 & 67,806 & -0.31 \\
\hline $51-55$ & 57,728 & 47,681 & 72,501 & -0.34 \\
\hline $56-60$ & 56,700 & 47,853 & 71,132 & -0.33 \\
\hline$\geq 61$ & 50,910 & 45,442 & 60,892 & -0.25 \\
\hline \multicolumn{5}{|l|}{ Tenure (years): } \\
\hline 0 & 44,811 & 37,305 & 48,467 & -0.23 \\
\hline $1-3$ & 48,450 & 41,254 & 55,190 & -0.25 \\
\hline $4-5$ & 51,494 & 43,894 & 62,120 & -0.30 \\
\hline $6-9$ & 54,499 & 45,759 & 67,555 & -0.32 \\
\hline $10-19$ & 53,780 & 47,748 & 70,560 & -0.32 \\
\hline $20+$ & 60,612 & 51,856 & 81,363 & -0.37 \\
\hline \multicolumn{5}{|l|}{ Ethnicity: } \\
\hline Pakeha & 52,578 & 45,453 & 60,825 & -0.25 \\
\hline Maori & 45,400 & 41,803 & 51,094 & -0.18 \\
\hline
\end{tabular}

\section{References}

Belman, D. and P.B. Voos (2004) 'Changes in union wage effects by industry: a fresh look at the evidence', Industrial Relations, 43 (3), pp.491-519.

Bender, K.A. (1998) 'The central government-private sector wage differential,' Journal of Economic Surveys, 12 (2), pp.177-220.

Blanchflower, D. and A. Bryson (2004) 'What effect do unions have on wages now and would Freeman and Medoff be surprised?', Journal of Labor Research, 25 (3), pp.383-414.
Card, D. (2001) 'The effect of unions on wage inequality in the U.S. labor market', Industrial and Labor Relations Review, 54 (2), pp.296-315.

Fang, T. and A. Verma (2002) 'Union wage premium', Perspectives on Labour and Income, 3 (9), pp.17-23.

Freeman, R.B. (1982) 'Union wage practices and wage dispersion within establishments', Industrial \& Labor Relations Review, 36 (1), pp.3-21.

—and J.L. Medoff (1984) What Do Unions Do?New York: Basic Books. 
Hansen, F. (1998) 'Union membership and the union wage differential', Compensation and Benefits Review, 30 (3) pp.16.

Harbridge, R. and A. Honeybone (1996) 'External legitimacy of unions: trends in New Zealand', Journal of Labor Research, 17, pp.425-44.

Hirsch, B.T. and E.J. Schumacher (2001) 'Private sector union density and the wage premium: past, present and future', Journal of Labor Research, 22 (3), pp.487-518.

Kornfeld, R. (1993) 'The effects of union membership on wages and employee benefits: the case of Australia', Industrial \& Labor Relations Review, 47 (1), pp.114-28.

Metcalf, D., K. Hansen and A. Charlwood (2001) 'Unions and the sword of justice: unions and pay systems, pay inequality and low pay', National Institute Economic Review, 176, pp.61-75.

Mishel, L. and M. Walters (2003) 'How unions help all workers', Economic Policy Institute briefing paper 143.

Peetz, D. (2001) 'Individual contracts, collective bargaining, wages and power', discussion paper 247, Centre for Economic Policy Research, Australian National University.

Waddoups, C.J. (2005) 'Trade union decline and union wage effects in Australia,' Industrial Relations, 44 (4), pp.607-24.

Walsh, P., R. Harbridge and A. Crawford (2001) 'Public sector industrial relations in New Zealand', in C. Dell'Aringa, G. Della Rocca and B. Keller (eds), Strategic Choices in Reforming Public Service Employment: an international handbook, New York: Palgrave.

Wooden (2001) 'Union wage effects in the presence of enterprise bargaining', The Economic Record, 77 (236), pp.1-18.

Goldie Feinberg-Danieli is a Research Fellow in the Victoria Management School, Victoria University of Wellington, and Zsuzsanna Lonti is a Senior Lecturer in the same school. 